\title{
Inorganic nitrogen absorption in the aquaponics farming of sangkuriang catfish Clarias gariepinus at uneven retention periods
}

\section{Penyerapan nitrogen anorganik pada budidaya lele sangkuriang Clarias gariepinus sistem akuaponik dengan periode retensi yang berbeda}

\author{
Zahidah $^{1 *}$, Yuli Andriani ${ }^{1}$, Yayat Dhahiyat ${ }^{1}$, Isni Nurruhwati ${ }^{1}$, Asep Sahidin ${ }^{1}$, Herman \\ Hamdani $^{1}$, Stephanie Marcelia Victoria ${ }^{1}$
}

${ }^{1}$ Faculty of Fisheries and Marine Science, Padjadjaran University.

*E-mail: ibuzah@gmail.com

(Received November 3, 2016; Accepted July 24, 2018)

\begin{abstract}
Aquaponics is new aquaculture integrating the technology of fishes and plants due to less availability of land. This study aimed to determine the optimum retention period in the aquaponics farming of sangkuriang catfish (Clarias gariepinus) integrated with water spinach (Ipomoea reptan) to generate the water to support the catfish production. This study conducted in 40 days between May to June 2016 at Ciparanje Fish Hatchery Laboratory, Faculty of Fisheries and Marine Sciences, Universitas Padjadjaran. The design of this study was completely randomized, with five treatments and three replications. The treatments retention periods were 5, 10, 15, 20 minutes, and control (no water flow). The study showed that the retention period affected water spinach's inorganic nutrient absorption in sangkuriang catfish farm. The 15 minutes retention period gave the most desirable result, with a flow of $0.072 \mathrm{~L} / \mathrm{s}$ that reduced $58.83 \%$ of nitrate, and $33.32 \%$ of ammonia has been produced by fish farming activities. The highest specific growth rate of the sangkuriang catfish obtained in 15 minute retention period of $4.01 \%$.
\end{abstract}

Keywords: aquaponics, sangkuriang catfish, water spinach, retention periods

\begin{abstract}
ABSTRAK
Akuaponik adalah teknologi akuakultur baru yang mengintegrasikan ikan dan tanaman karena ketersediaan lahan yang semakin rendah. Penelitian ini bertujuan untuk menentukan periode retensi optimum pada budidaya akuaponik ikan lele sangkuriang (Clarias gariepinus) yang terintegrasi dengan kangkung air (Ipomoea reptan) untuk menghasilkan air yang mendukung produksi lele. Penelitian ini dilakukan selama 40 hari di Laboratorium Budidaya Ikan Ciparanje, Fakultas Perikanan dan Ilmu Kelautan, Universitas Padjadjaran. Penelitian ini menggunakan rancangan acak lengkap, dengan lima perlakuan dan tiga kali ulangan. Perlakuan berupa periode retensi 5, 10, 15, 20 menit, dan kontrol (tidak ada aliran air). Hasil penelitian menunjukkan bahwa periode retensi memengaruhi penyerapan nutrisi anorganik oleh bayam air dalam budidaya ikan lele sangkuriang. Periode retensi 15 menit memberikan hasil yang paling baik, dengan aliran 0,072 L/s mengurangi 58,83\% nitrat, dan 33,32\% amonia dalam media budidaya ikan. Laju pertumbuhan spesifik ikan lele sangkuriang tertinggi diperoleh pada perlakuan waktu retensi 15 menit, yaitu sebesar 4,01\%.
\end{abstract}

Kata kunci: akuaponik, ikan lele sangkuriang, kangkung darat, waktu retensi 


\section{INTRODUCTION}

Limited land area and water resources are kinds of problems in increasing the production of freshwater aquaculture. In addition to depletion of land area and the limitation of water resources, another problem of aquaculture is waste that potentially pollutes the aquatic environment. According to Yokoyama et al. (2010), intensive fish farming will generate large amounts of particulate organic wastes in the form of waste feed (WF) and fecal matter (FM). The particulate organic wastes settle onto the seabed and produce enriched sediments, which can result in the deoxygenation of the bottom water, the production of reduced compounds such as ammonium and sulfides. The result showed that feed will become waste feed (29\%) exceeded fecal matter (12\%) in the water. The similar result showed by Barrows and Frost (2014), that in a properly managed farm, approximately $30 \%$ of the feed used will become fecal waste. The availability of land and water for aquaculture is getting less due to population growth and physical development. To overcome these problems, innovation in aquaculture is needed.

One of the innovations that have been developed were integrated farming of fish with a plant known as aquaponics. Aquaponics is the integration of aquaculture with hydroponics. In this integrated system, waste generated from aquaculture subsystem become an input to hydroponics subsystem. The residue of feed, feces, and urine of fish contain nutrients are used as fertilizer for plants in the hydroponic subsystem. While the plants in hydroponic play a role as a biofilter that absorbed the generated waste from aquaculture system.

In the aquaculture system, water quality plays an important role. Aquaculture wastes derived from feed residue and metabolic waste, including feces that contained ammonia (White, 2013). Accumulation of ammonia in the culture media is one of the causes of decreasing water quality that affects aquaculture success. These will later ignite domino effects that are both economically and ecologically devastating (Lazzari \& Baldisserotto, 2008; Harry et al., 2014). Selection of grown commodities in the aquaponics system should be considered to obtain a maximum result. Species of fish that cultured often in aquaponics systems include tilapia, carp, koi, catfish, and prawns. Catfish is one of fish that selected often in aquaponics because catfish produced more feces than other fishes. The plant that used for aquaponics as a biofilter in absorbing nitrogen in form of ammonium $\left(\mathrm{NH}_{4}{ }^{+}\right)$and nitrate $\left(\mathrm{NO}_{3}{ }^{-}\right)$, in order to reduce the nitrogen content in water (Effendi et al., 2015; Wahyuningsih et al., 2015). The plants should have an economic value, like water spinach, because the selling price is high. Water spinach is a plant cultured in a short time. The previous study that showed an integration between fish with water spinach comes from Setijaningsih and Umar (2015), stated that water spinach was able to reduce nitrogen waste from fish cultured up to $58 \%$.

In aquaponics, water flow from the aquaculture subsystem to the hydroponics subsystem will affect the absorption of nitrogen by plants (Ezekiel, 2015). The interaction between the water in rearing tanks with plant roots influenced by the duration of water flooded the plant roots. A study in aquaponics was more likely about stocking densities and different kinds of fishes, plant productivity, substrate type, and modified filter (Mulqan et al., 2017; Nuwansi et al., 2017; Schmautz et al., 2016). While an assessment of water retention time in the medium plant has not been done yet (Yilzid et al., 2017).

Continuous water recirculation from fish rearing tanks outlet to plant media returned to rearing tanks inlet caused uneven absorption of nutrients by the plant (Danaher et al., 2013). According to Ratannanda (2011), low retention time could cause short contact between the water and the plant roots, so the nitrogen would return to fish rearing tanks caused nitrogen concentration remains high. Based on this, it suspected that the longer retention time, the higher the reduction rate of nitrogen in fish rearing tanks. The water quality improvements made by plants aims to maintain water quality in aquaculture containers (Yildiz et al., 2017). This study aimed to determine the optimum retention period in the aquaponics farming of sangkuriang catfish (Clarias gariepinus) integrated with water spinach (Ipomoea reptan) to generate water to supports catfish production.

\section{MATERIALS AND METHODS}

The study conducted over 40 days at Ciparanje hatchery, Faculty of Fisheries and Marine Sciences, Padjadjaran University, Jatinangor. Water sampling test for inorganic nutrients conducted for 10 days to be tested in the Laboratory of Aquatic Resources Management. 
The catfish Clarias gariepinus sizing of 9-11 $\mathrm{cm}$ in length with a mean body weight of $7 \mathrm{~g}$ were stocked at a density of 100 individuals $/ \mathrm{m}^{2}$. The catfish fry was taken from The Development Center of Freshwater Aquaculture (BPBAT) Subang, West Java. Water spinach Ipomoea reptan sizing of $4 \mathrm{~cm}$ in high, planted in Rockwool substrate as much as five clumps for each rearing tanks. The water spinach sprouts that used were $7-10 \mathrm{~cm}$ high and were previously seeded at Ciparanje rearing tanks. Water spinach seed integrated 14 days after the fishes were stocked. Water spinach seed obtained from Begonia Farm Garden Lembang, West Java.

The study used a completely randomized design (CRD) with five treatments included treatment A: aquaponics system without setting a retention time (control), treatment B: aquaponics system with a retention time of 5 minutes, treatment $C$ : aquaponics system with a retention time of 10 minutes, treatment $\mathrm{D}$ : aquaponics system with a retention time of 15 minutes, and treatment $\mathrm{E}$ : aquaponics system with a retention time of 20 minutes. They all had three replications.

Fishes were cultured in 15 cubical fiberglass sizing $1 \times 1 \times 0.3 \mathrm{~m}$ in dimension. The receptacles for plant growth were made of PVC measuring $100 \times 15 \times 10 \mathrm{~cm}$ (Figure 1). Reduction of inorganic nitrogen calculated by this formulation :

$$
\% \text { reduction }=\mathrm{Ci}-\mathrm{Co} / \mathrm{Ci} \times 100 \%
$$

$\mathrm{Ci}=$ value at inlet plant tank

$\mathrm{Co}=$ value at outlet plant tank

\section{Data analysis}

Analysis of variance at $95 \%$ confidence interval was used for testing the effect of treatment on the growth rate and survival rate of catfish then it continued with Duncan multiple range test. In the meantime, the percentage reduction of nitrogen was analyzed descriptively. Water quality parameters included dissolved oxygen (DO), $\mathrm{pH}$, temperature maintained within the optimal range for fish farming. Nitrate and total ammonia nitrogen were analyzed and compared to the standard quality for fisheries under the Indonesian Government Regulation No. 82 of 2001 (Sekretariat Negara, 2001).

\section{RESULTS AND DISCUSSION}

\section{Inorganic nitrogen concentration}

The fluctuation of inorganic nitrogen concentrations during the study shown in Figure 2. At the beginning of the study, the nitrate concentration in all treatments was still high and the concentration was decreased at day 10 , relatively low nitrate concentrations have shown until day 30, and increased at the end of the study at day 40. The pattern of fluctuations was the same for all treatments.

Low concentrations of nitrate at the beginning of periods occurred due to untapped nitrates by water spinach. In the second and third sampling, nitrate concentration was decreased, then at the last period (day 40) nitrate concentration has increased significantly. This happened due to at the end of the study period, ammonia as residual metabolism derived by catfish higher than the previous periods. Through the nitrification process, ammonia is converted into nitrate, so that the concentration of nitrate in the period returned high. Nitrification bacteria needs the media to carry out nitrification process in the root of the plant, if the plant was not integrated enough, then nitrification bacteria exist in small amounts. At the end of the period, nitrate concentration was exceeded from nutrient needs for five clumps of water spinach, so some of the nitrates were not

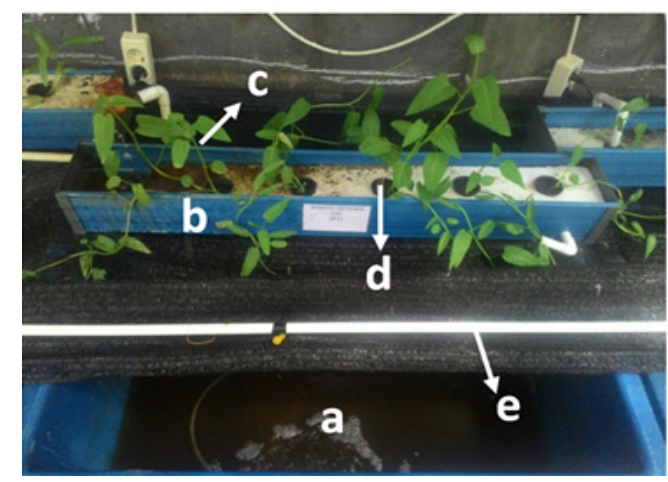

Note: $\mathrm{a}=$ Fish tank, $\mathrm{b}=$ plant tank.c $=$ plant, $\mathrm{d}=$ Net pot, $\mathrm{e}=$ Water circulator tool Figure 1. Aquaponics system design 


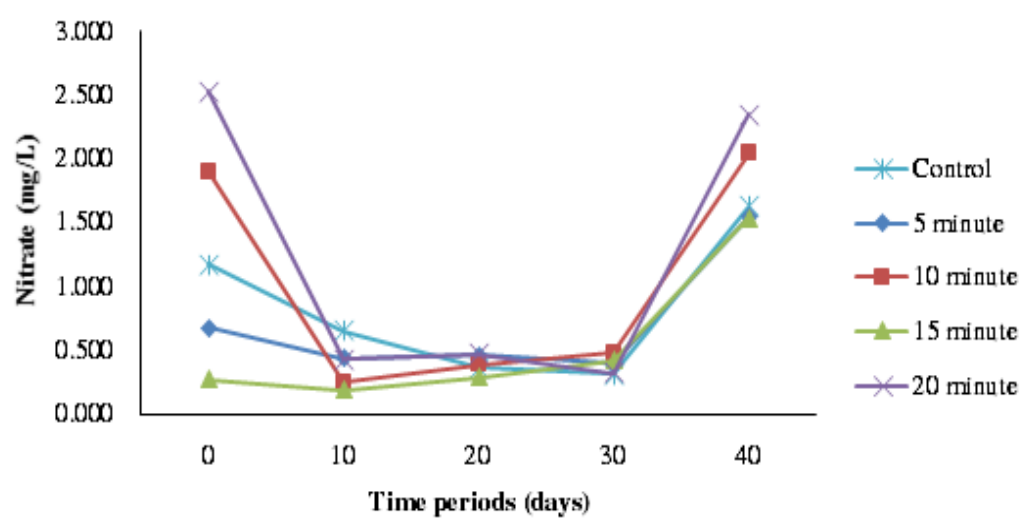

Figure 2. Fluctuation of inorganic nitrogen (nitrate) in aquaponics system catfish and water spinach with uneven retention periods

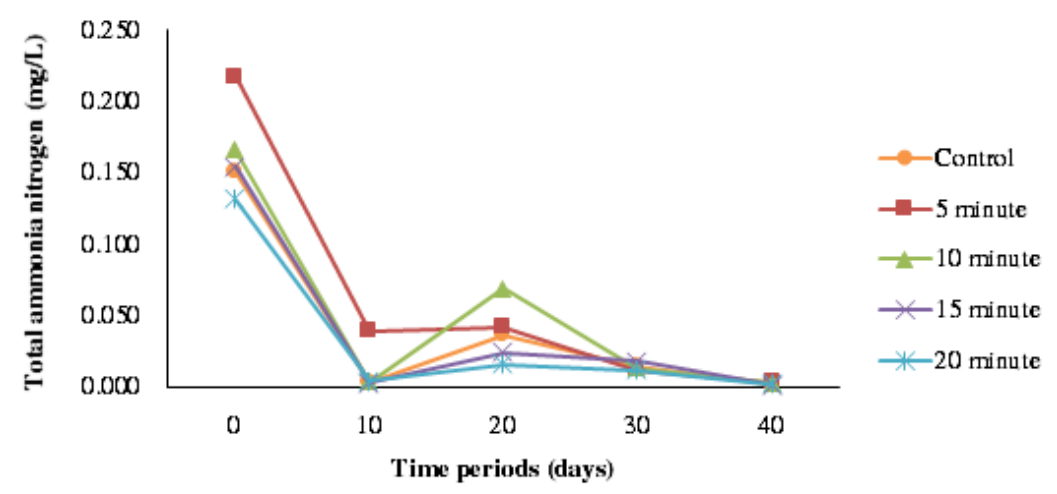

Figure 3. Fluctuation of inorganic nitrogen (TAN) in aquaponics system catfish and water spinach with uneven retention periods.

absorbed and returned into aquaculture rearing tanks (Crab et al., 2007; Zou et al., 2015). Based on nitrate concentration and absorption of the plant with a maximum retention time of 15 minutes, the number of water spinach clumps can be added to more than five clumps. According to FAO (2009), the resistance of nitrification bacteria activity was encountered when the biofilter is too small to accommodate the metabolic waste and uneaten feed.

Aquaponics system is close to nitrification in aquaculture rearing tanks. The inorganic nitrogen is contained in water in the form of ammonia $\left(\mathrm{NH}_{3}\right)$, ammonium $\left(\mathrm{NH}_{4}{ }^{+}\right)$, nitrite $\left(\mathrm{NO}_{2}\right)$, nitrate $\left(\mathrm{NO}_{3}\right)$, and $\mathrm{N}_{2}$ gasses. Nitrification process is a process of autotrophic bacteria using oxygen to convert the ammonia into nitrite by bacteria Nitrosomonas and nitrite converted into nitrate by Nitrobacter (Zou et al., 2015). Nitrate is a macronutrient for plants. Nitrate compounds are used by plants and phytoplankton for growing process (Brahmana et al., 2010). Nitrate concentrations in the rearing tanks at the beginning of this study was still high because it had not been utilized by plants yet. Nitrate concentrations were decreased on day 10 as it began to be used by plants as a nutrient. Nitrates are not toxic for fish unless at a concentration of more than $10 \mathrm{mg} / \mathrm{L}$ (Camargo et al., 2005). Nitrate concentrations at day 20 and 30 have fluctuated. Increasing and decreasing of nitrate concentrations were influenced by the activity of nitrification bacteria that affected by temperature, dissolved oxygen (DO), and $\mathrm{pH}$. In this study, $\mathrm{DO}$ and $\mathrm{pH}$ was maintained in optimal conditions for the nitrification process (Dauhan $e t$ al., 2014).

Based on the results, nitrate, and total ammonia nitrogen (TAN) in rearing tanks obtained the lowest range in retention times of 10 and 15 minutes. The lowest nitrate concentration was at a retention time of 15 minutes which were 0.185 to $1.581 \mathrm{mg} / \mathrm{L}$, the lowest concentration of ammonia at a retention time of 10 minutes with a range of 0.001 to $0.186 \mathrm{mg} / \mathrm{L}$. Referred to the Indonesian Government Regulation No. 82 of 2001 (Sekretariat Negara, 2001), it can be stated that the concentration of nitrate and TAN are in the range of feasible for all classes of water, i.e. less than $10 \mathrm{mg} / \mathrm{L}$ for nitrate and less than $0.5 \mathrm{mg} / \mathrm{L}$ for TAN. Here are inorganic nitrogen fluctuations showed in Figure 2 and 3. 


\section{The percentage of inorganic nitrogen reduction}

The percentage reduction of inorganic nitrogen absorbed by water spinach on the aquaponics system is shown in Table 1 . The highest value showed at 10 minutes retention time amounted to $71.82 \%$. The percentage reduction of nitrate was $23.62-71.82 \%$, the lowest percentage reduction in 5 minutes retention time of was $18.12 \%$. The percentage reduction of ammonia ranged between $18.58-33.32 \%$, the lowest percentage in the retention time of 10 minutes amounted to $18.58 \%$ and the highest value is shown in retention time of 15 minutes was $33.32 \%$. The percentage reduction of phosphate ranged between $22.25-28.07 \%$ and the lowest percentage was in retention time of 10 minutes, it was to $22.25 \%$, and the highest percentage in retention time of 20 minutes was $28.07 \%$.

Table 1. The percentage of inorganic nitrogen reduction

\begin{tabular}{ccc}
\hline $\begin{array}{c}\text { Retention time } \\
\text { (minutes) }\end{array}$ & Nitrate (\%) & Ammonia (\%) \\
\hline 5 & $23.62 \pm 0.360$ & $24.75 \pm 0.153$ \\
10 & $71.82 \pm 0.140$ & $18.58 \pm 0.080$ \\
15 & $58.33 \pm 0.206$ & $33.32 \pm 0.185$ \\
20 & $57.76 \pm 0.116$ & $24.02 \pm 0.152$ \\
Control & $48.67 \pm 0.318$ & $41.00 \pm 0.121$ \\
\hline
\end{tabular}

The highest percentage reduction of nitrate found in rearing tank with a retention time of 10 minutes, it was $71.82 \%$, while the lowest nitrate concentration found at a retention time of 15 minutes, it was $0.191 \mathrm{mg} / \mathrm{L}$. Concerning in water change, the retention time of 10 minutes was $47 \%$ or more compared to a retention time of 15 minutes was $31 \%$, it caused a contact between the water and the plant short compared with the change of water retention time of 15 minutes. Water change in a retention time of 15 minutes showed the best efficiency in absorbing nitrate, thereby reducing the nitrates in rearing tanks aquaculture system with the second highest percentage reduction was $58.33 \%$.

The highest percentage reduction of ammonia in a retention time of 15 minutes was $33.32 \%$ among the lowest concentration of $0.003 \mathrm{mg} / \mathrm{L}$. According to Ratannanda (2011) as the increase in the percentage change of water, every day would increase dilute media cultivation. It reflected on decreasing concentrations of ammonia, nitrates, and nitrites in the cultivation media. The absorption of ammonia obtained from the percentage reduction of ammonia concentration in rearing tanks aquaculture, this indicated that the optimum absorption occurred a retention time of 15 minutes in decreasing the concentration of ammonia in rearing tanks aquaculture as much as $33.32 \%$.

Water spinach grows by utilizing the nutrients from the waste of catfish farming. Inorganic nitrogen is used for forming the structure formation of plants, chlorophyll formation, photosynthesis, cell growth, and metabolic processes (FAO, 2009). Growth in length and number of leaves is an absolute calculation. Stem length growth was highest in the control treatment amounted to $41.83 \mathrm{~cm}$ and the lowest was in retention time of 10 minutes that reached $36.50 \mathrm{~cm}$. The highest number of leaves addition showed retention time of 20 minutes with 11 leaves and the lowest was in the control treatment showed only three leaves. The highest growth on the control stem length occurred due to absorption of inorganic nutrients that used for stem growth due to water contact time containing nutrients to plant roots was relatively shorter than other treatments. It caused a lack of nutrients from root to stem and did not support the accretion of the leaves (Table 2).

Table 2. Water spinach average growth

\begin{tabular}{ccc}
\hline $\begin{array}{c}\text { Treatment } \\
(\mathrm{min})\end{array}$ & $\begin{array}{c}\text { Plant high } \\
(\mathrm{cm})\end{array}$ & $\begin{array}{c}\text { Leaf amount } \\
\text { (pieces) }\end{array}$ \\
\hline 5 & $40.90 \pm 21.71$ & 5 \\
10 & $36.50 \pm 3.73$ & 5 \\
15 & $38.40 \pm 9.65$ & 7 \\
20 & $39.80 \pm 20.04$ & 11 \\
Control & $41.83 \pm 10.79$ & 3 \\
\hline
\end{tabular}

The retention time of 5 minutes reduced $23.63 \%, 24.75 \%$ ammonia, and nitrate respectively, and able to support plant productivity by $40.9 \mathrm{~cm}$ in high and increased the number of leaves to five pieces. The plant high in retention time of 10 minutes was $36.5 \mathrm{~cm}$ and the number of leaves supported by the nitrate uptake as much as $71.82 \%$ and $18.58 \%$ of ammonia. Treatment retention time of 15 minutes absorbed nitrate of $58.33 \%$ and ammonia of $33.32 \%$ and was able to support the growth of the plant to $38.4 \mathrm{~cm}$ and increase the number to seven pieces. While retention time in 20 minutes treatment shown a number of leaves to 11 with stems growth length reached $39.80 \mathrm{~cm}$.

\section{Survival rate}

For 40 days rearing catfish on aquaponics system, the survival rate ranged between 55-67\% (Figure 4). Statistical analysis showed there were 


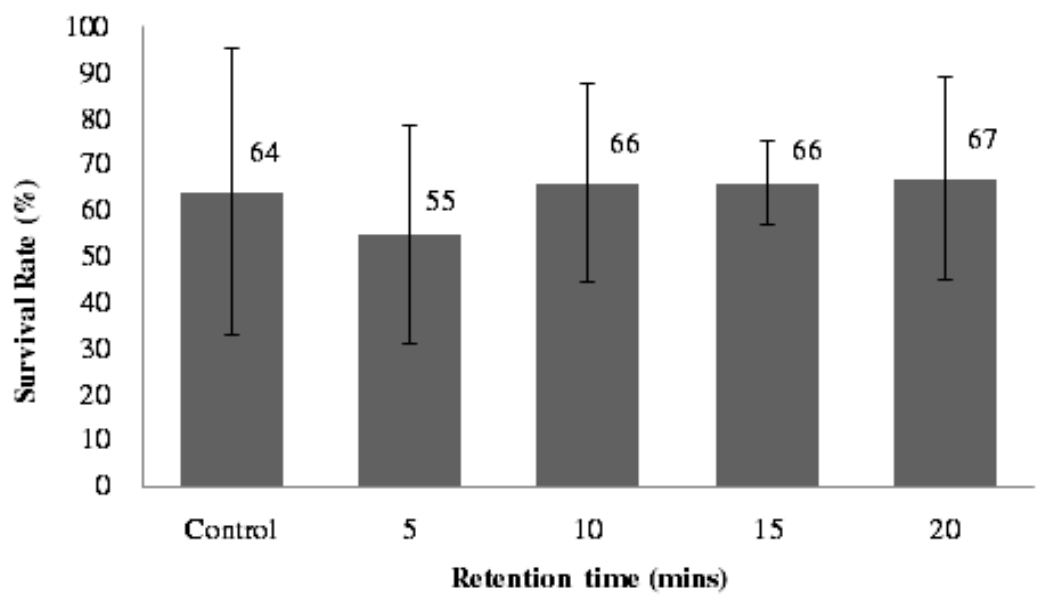

Figure 4. Catfish survival rate.in aquaponics system with uneven retention periods.

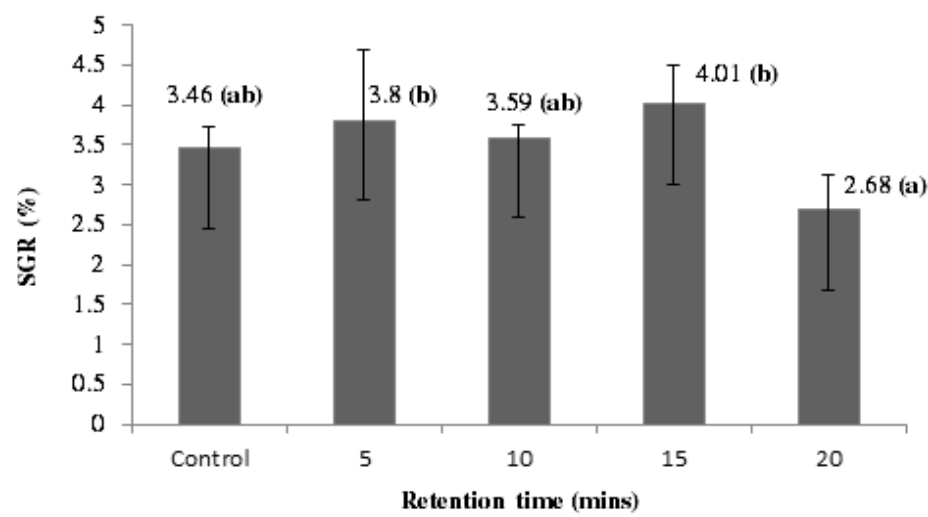

Figure 5. The specific growth rate in aquaponics system with uneven retention periods (SGR). Numbers that are followed by the same letter shows the insignificant difference between treatments according to Duncan's multiple range test (p-value 0.05$)$.

no significant differences among the treatments.

Catfish is a species that ideal to be reared in aquaponics because they have a breathing apparatus to help them survive in low dissolved oxygen condition, so they do not affect (FAO, 2009). Fish death has occurred in the early period of the study (first 10 days) because it was an effect of the acclimation process. After 10 days, the mortality rate reduced and reached $67 \%$ in retention time of 20 minutes of treatment.

\section{Specific growth rate}

The highest catfish specific growth rate obtained in retention time of 15 minutes, reached $4.01 \%$ per day, while the lowest growth rate occurred in 20 minutes retention time of which reached $2.68 \%$ per day. Specific growth rate can be seen in Figure 5. Based on statistical analysis, it is known that treatment retention time of 15 minutes was not significantly different with retention treatment of 5 minutes and 10 minutes, but significantly different from the control and retention treatment of 20 minutes. The result is similar to Wicaksana et al. (2015) study which showed that a specific growth rate of catfish in an aquaponics system are better than a conventional system. Furthermore, it is stated because water quality on media can be maintained with the existence of the plant as a biofilter.

\section{CONCLUSIONS}

The most effective retention time to absorb inorganic nitrogen content is in 15 minutes as much as $58.83 \%$ of nitrate and $33.32 \%$ of ammonia. The retention time of 15 minutes showed the highest specific growth rate of catfish, while the highest growth of water spinach obtained at a retention time of 20 minutes.

\section{REFERENCES}

Barrows FT, Frost J. 2014. Evaluation of modified processing waste from the nut industry, algae and an invertebrate meal for rainbow trout 
Oncorhynchus mykiss. Aquaculture 434: 315-324.

Brahmana SS, Summarriani Y, Ahmad F. 2010. Water quality and eutrophication of Right Rice Reservoir in South Kalimantan [Proceeding]. Bogor: Seminar Nasional Limnologi ke-V.

Camargo JA, Alonso A, Salamanca A. 2005. Nitrate toxicity to aquatic animals: a review with new data for fteshwater invertebrates. Chemospere 58: 1255-1267.

Crab R, Avnimelech Y, Defoirdt T, Bossier P, Verstraete W. 2007. Nitrogen removal techniques in aquaculture for a sustainable production. Aquaculture 270: 1-14.

Danaher J, Shultz RC, Rakocy JE, Bailey DS. 2013. Alternative solids removal for warm water recirculating raft aquaponic system. Journal of the World Aquaculture Society 44: 374-383.

Dauhan RES, Efendi E, Suparmono. 2014. Efektifitas sistem akuaponik dalam mereduksi konsentrasi ammonia pada sistem budidaya ikan. E-Jurnal Rekayasa dan Teknologi Budidaya Perairan 3: 20-29.

Effendi H, Utomo BA, Darmawangsa GM. 2015. Phytoremediation of freshwater crayfish Cherax quadricarinatus culture wastewater with spinach Ipomoea aquatica in aquaponic system. AACL BIOFLUX 8: 421-430.

Ezekiel O. 2015. Effectiveness of aquaponic and hydroponic gardening to traditional gardening. International Journal of Scientific Research and Innovative Technology 2: 21-52.

[FAO] Food and Agriculture Organization. 2009. The State of World Fisheries and Aquaculture. Rome: SOFIA.

Harry WP, Robert S, Sebastian W, Ulrich K. 2014. Significant factors affecting the economic sustainability of closed aquaponic systems. Part I: system design, chemo-physical parameters and general aspects. AACL BIOFLUX 7: 20-32.

Lazzari R, Baldisserotto B. 2008. Nitrogen and phosphorus waste in fish farming. Boletim do Instituto de Pesca 34: 591-600.

Mulqan M, El Rahimi SA, Dewiyanti I. 2017. The growth and survival rate of tilapia juvenile Oreochromis niloticus in aquaponics system with different plants species. Jurnal Ilmiah Mahasiswa Kelautan dan Perikanan Unsyiah 2: 183-193.

Nuwansi KKT, Verma AK, Tiwari VK, Chandra P, Chandrakant MH. 2017. Standardization of the stocking density ratios of koi carp
Cyprinus carpio: goldfish Carassius auratus in polyculture aquaponic recirculating system. Turkish Journal of Fisheries and Aquatic Science 17: 1271-1278.

Ratannanda R. 2011. Determination of retention time aquaponic system to reduce waste cultured tilapia Oreochromis sp. [Skripsi]. Program Sarjana, Institut Pertanian Bogor, Bogor.

Schmautz Z, Fionna L, Frank L, Andreas G, Alex M, Tjasa GB, Ranka J. 2016. Tomato productivity and quality in aquaponics: comparison of three hydroponic methods. Water 8: 1-21.

Setijaningsih L, Umar C. 2015. Effect of water retention on the growth of Nile tilapia Oreochromis niloticus in the aquaponic system with water spinach Ipomoea reptans. Jurnal Ilmu-Ilmu Hayati 14: 267-275.

Sekretariat Negara. 2001. Indonesian Government Regulation No. 82 of 2001 (Peraturan Pemerintah Republik Indonesia No 82) tentang pengelolaan kualitas air dan pengendalian pencemaran air. https://www.slideshare.net/.../ pp-82-th-2001-

Wahyuningsih S, Effendi H, Wardiatno Y. 2015. Nitrogen removal of aquaculture wastewater in aquaponic recirculation system. AACL BIOFLUX 8: 491-499.

White PG. 2013. Environmental consequences of poor feed quality and feed management. In. MR Hasan and MB New (eds). On-farm feeding and feed management in aquaculture. FAO Fisheries and Aquaculture Technical Paper 583: 553-564.

Wicaksana SN, Hastuti S, Arini E. 2015. Performance of dumbo catfish production Clarias gariepinus maintained with ionic and conventional biofilter systems. Journal of Aquaculture Management and Technology 4: 109-106.

Yildiz HY, Robaina L, Pirhonem J, Mente E, Dominguez D, Parisi G. 2017. Fish welfare in aquaponic system: its relation to water quality with an emphasis on feed and faeces. Water 9: $1-17$.

Yokoyama H, Ishihi Y, Abo K, Takashi T. 2010. Quantification of waste feed and fish feces using stable carbon and nitrogen isotopes. Bulletin of Fisheries Research Agency 31: 71-76.

Zou Y, Zhen H, Jian Z, Huijun X, Christophe G, Yingke F. 2016. Effect of $\mathrm{pH}$ on nitrogen transformation in media-based aquaponics. Bioresource Technology 210: 81-87. 